\title{
Treatment of Sewage Water Through Constructed Wetland by Typha Latifolia
}

\author{
Kamal B , Anitha Selvasofiya S.D , Jeevanandham V , Santhosh P Y , Santhosh Kumar V
}

\begin{abstract}
In India, about 38,255 million liters of sewage produced daily, out of which only $22 \%$ of the sewage is being treated. Wetland construction is a solution for the treatment of sewage water through the natural process of growing a plant. In this experimental setup, a wetland is constructed to investigate the performance of Typha latifolia when planted in sewage water and investigated for a period of 4 weeks. The constructed wetland $(C W)$ setup was filled with sewage water with a hydraulic retention period of 7 days. Within the stipulated period of 4 weeks, the change in the characteristics of the sewage was tested for every 7 days. During the treatment period, the plant Typha latifolia has considerably reduced the chloride content by $29.69 \%$ and the BOD content by $20.51 \%$ in the sewage. Hence, it is inferred from the project that the plant species Typha latifolia has the ability to reduce the saline nature of the water. It is also noted that the efficiency of the treatment of sewage water by the plant species increases with the increase in the time period in which the $C W$ system is maintained properly.
\end{abstract}

Keywords : Constructed wetland, Typha latifolia, sewage water, chloride content, Biochemical Oxygen Demand (BOD).

\section{INTRODUCTION}

Constructed wetlands are the methods of wastewater treatment through green technology. Constructed wetlands offer a land-intensive, low-energy, and less-operational-requirements alternative to conventional treatment systems, especially for small communities and remote locations [9]. There are various small communities located in the rural region where there are no adequate facilities for domestic wastewater treatment. One best option that can be adopted for such cases is that the construction of artificial wetlands that has the ability to treat wastewater in an environmental friendly manner [13]. The constructed wetland is designed in such a way that the wetland hydraulics, namely the hydraulic loading rates (HLR) and the hydraulic retention time (HRT) are maintained, as it affects the treatment performance of a wetland [5]. The constructed wetland system does not requires high construction and operation costs as it is required for the construction for a conventional wastewater treatment system. Wetlands use only the natural energy for the removal of pollutants which is a sustainable process [23]. CW's removes wastewater

Revised Manuscript Received on December 05, 2019.

Kamal B, Assistant professor, Civil Engineering Department, Sri Ramakrishna Engineering College, Coimbatore, India. Email: kamal.bsrm@gmail.com

Anitha Selvasofiya S., Assistant professor, Civil Engineering Department, Sri Ramakrishna Engineering College, Coimbatore, India. Email: anitha.sofiya@srec.ac.in

Jeevanandham V ${ }^{3}$, Santhosh $\mathbf{P} Y^{3}$, Santhosh Kumar V ${ }^{3}$, B.E Students, Civil Engineering Department, Sri Ramakrishna Engineering College, Coimbatore, India. pollutants and pathogens through a complex variety of physical, chemical and biological process. Recent report of literature point that pollutants can highly remove efficiencies often observed at the high loading rates characteristic of treatment situation [21]. The root system does the most active and important process in the constructed wetlands where physicochemical and biological processes take place that is induced by the interaction of plants, microorganisms, the soil, and pollutants [29]. The constructed wetland system removes the organic matter by the help of anaerobic bacteria attached to the porous media and plant roots. The plant roots not only acts a surface for the growth of bacteria but also provides oxygen for the growth of the plant [3]. As wastewater passes through the media of subsurface flow constructed wetland, the pollutants that are present in the wastewater are removed by the process taking place in the wetland [25]. The macrophytes can improve BOD and bacterial removal from wastewater through sedimentation, mechanical filtration, nutrient assimilation, oxygenation, and microbial attachment mechanisms, others did not detect any significant difference planted and unplanted systems. [1]. Available oxygen in CW's is an important factor in the degradation of organic matter and transformation of ammonium-nitrogen both of which are oxygen limiting process [17].

\section{OBJECTIVES}

The main objectives of the project are

- To find out the characteristics of the wastewater.

- To design an effective wetland system for wastewater treatment.

- To treat wastewater in a constructed wetlands.

- Compare the characteristics of wastewater before and after the wetland treatment system.

- To infer that the wetland has considerably reduced the concentration of any parameter in the wastewater sample taken.

\section{MTAERIALS}

The wetland construction system is designed based on raw water characteristics of sewage wastewater. The main design criteria for this construction are organic loading rate, hydraulic loading rate, retention time and depth of water. The Constructed Wetland (CW) system consists of a rectangular treatment cell made up of glass. The dimensions of the $\mathrm{CW}$ system are $0.3 \mathrm{~m}$ in length, $0.3 \mathrm{~m}$ in width and 0.3 $\mathrm{m}$ in height. The plant species used in the $\mathrm{CW}$ system is

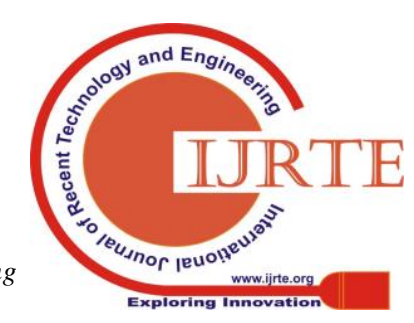


Typha latifolia which is commonly known as Cattail. The water sample used in the CW system is sewage wastewater. The water sample is collected from the Sewage Treatment Plant at Sri Ramakrishna Engineering College before the water enters the treatment plant. A layer of gravel is placed at the bottom of the tank for the plant to stand erect in the water surface without falling down. The size of the gravel varies from $2.36 \mathrm{~cm}$ to $5.73 \mathrm{~cm}$.

\section{METHODOLOGY}

The process of the project starts from the work of collecting the sewage water that is to be used in the Constructed Wetland system. Before the setup was installed the initial characters of the plant species such as the height of plant and the characteristics of the sample sewage water in which the plant is going to be grown are noted. Typha latifolia plant was placed at the exact center of the CW treatment cell. Sewage water is filled in the tank to a height of $0.2 \mathrm{~m}$ from the bottom surface of the tank and gravel is placed to a height of $0.13 \mathrm{~m}$ from the bottom of the tank. The gravel acts as a filtration medium that allows the solid particles in the sewage water to settle down thus the clear water is retained at the top surface. The plant was kept under observation for a period of 4 weeks. The characteristics of the water sample were tested at an interval of 7 days. The plant was grown in the constructed wetland setup with a hydraulic retention period of 7 days. At the end of 4th week, the characteristics of the sewage water are compared with the characteristics of the raw sewage. Form the comparison of the results it is inferred about the efficiency of the plant in the $\mathrm{CW}$ system in treating the sewage water.

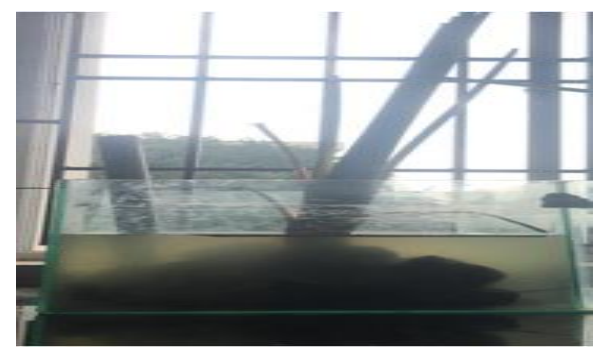

Fig. 1. Setup of the Constructed Wetland

There are various tests performed on the wastewater to determine it characteristics. The physical, chemical and biological tests are performed as per Indian standard, APHA and WHO standards.

\section{A. Physical Test}

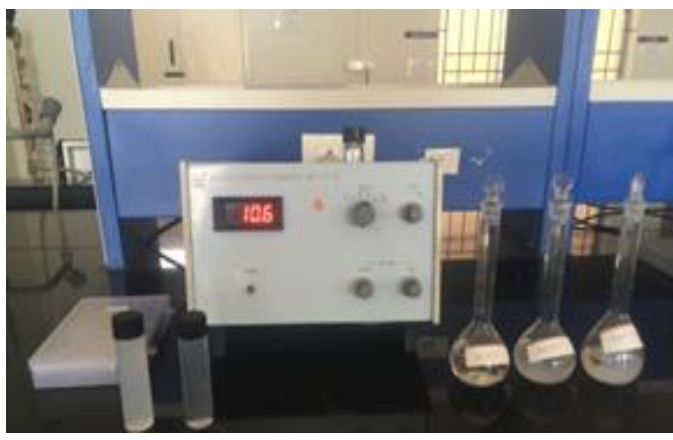

Fig.2. Turbidity test

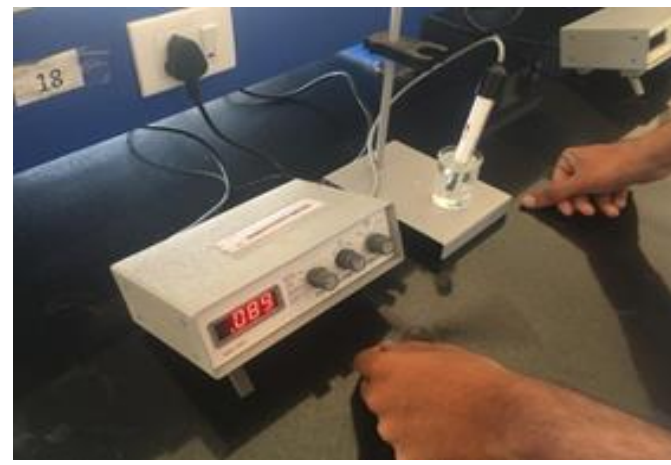

Fig.3. Electrical conductivity test

\section{B. Chemical Test}

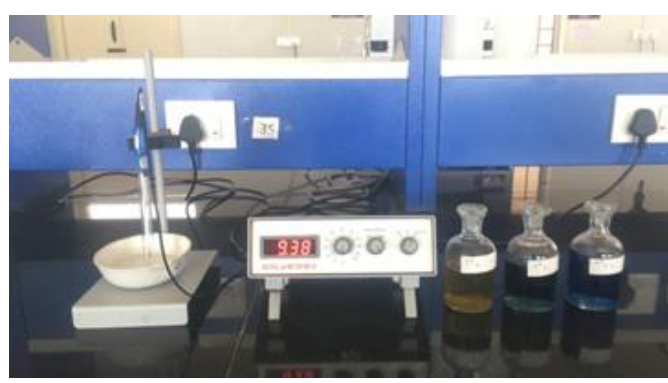

Fig. 4. pH test

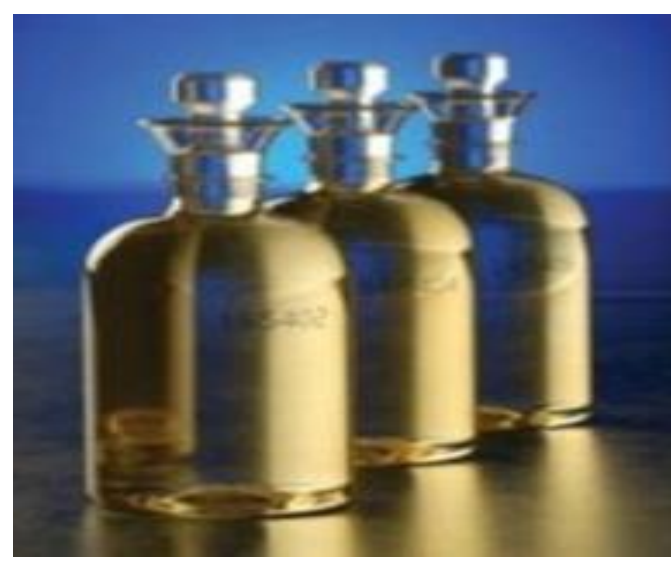

Fig.5. Biochemical Oxygen Demand test

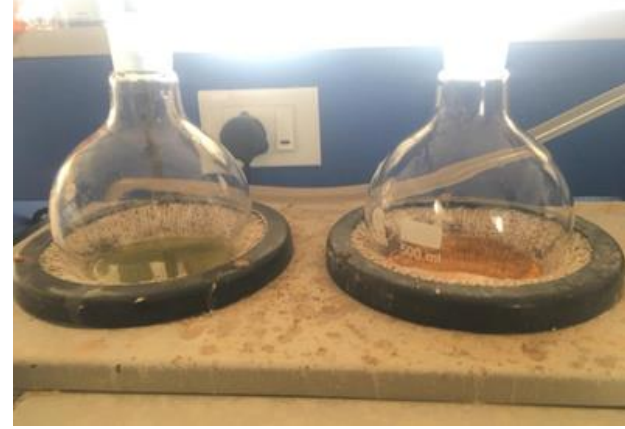

Fig. 6. Chemical Oxygen

Demand test 


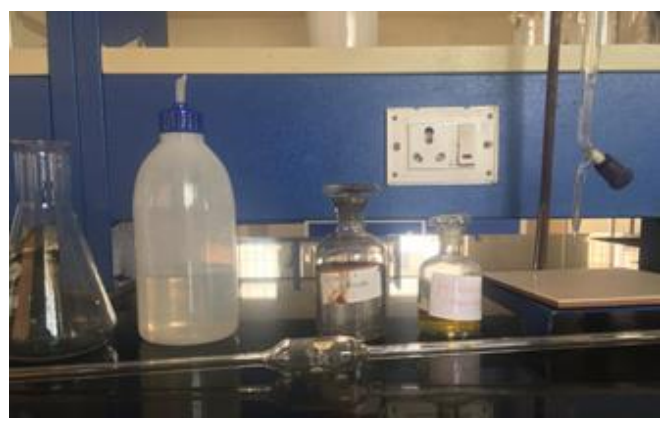

Fig. 7. Chloride test

\section{RESULTS AND DISCUSSION}

The plant species Typha latifolia was installed in the wetland setup and investigated for a period of 4 weeks with a hydraulic retention period of 7 days. The characteristics of the sewage were tested periodically every week and the results were noted from the tests. The noted results of the sewage every week are listed in the table below.

Table I: Results of the test conducted on sample water

\begin{tabular}{|c|c|c|c|c|c|}
\hline Particulars & Initial & Week 1 & Week 2 & Week 3 & Week 4 \\
\hline Height of plant & $45 \mathrm{~cm}$ & $58 \mathrm{~cm}$ & $79 \mathrm{~cm}$ & $93 \mathrm{~cm}$ & $122 \mathrm{~cm}$ \\
\hline $\begin{array}{l}\text { Colour of } \\
\text { water }\end{array}$ & $\begin{array}{l}\text { Yellowis } \\
\mathrm{h} \text { colour }\end{array}$ & $\begin{array}{l}\text { Pale } \\
\text { yellow }\end{array}$ & $\begin{array}{l}\text { Pale } \\
\text { yellow }\end{array}$ & $\begin{array}{l}\text { Pale } \\
\text { green }\end{array}$ & $\begin{array}{l}\text { Pale } \\
\text { green }\end{array}$ \\
\hline Odour & Stinky & Stinky & $\begin{array}{l}\text { No } \\
\text { smell }\end{array}$ & $\begin{array}{l}\text { No } \\
\text { smell }\end{array}$ & $\begin{array}{l}\text { No } \\
\text { smell }\end{array}$ \\
\hline Temperature & $27^{\circ} \mathrm{C}$ & $27^{\circ} \mathrm{C}$ & $27^{\circ} \mathrm{C}$ & $27^{\circ} \mathrm{C}$ & $27^{\circ} \mathrm{C}$ \\
\hline Turbidity & $\begin{array}{l}60.1 \\
\text { NTU }\end{array}$ & $\begin{array}{l}47.24 \\
\text { NTU }\end{array}$ & $\begin{array}{l}33.24 \\
\text { NTU }\end{array}$ & $\begin{array}{l}19.17 \\
\text { NTU }\end{array}$ & $\begin{array}{l}10.8 \\
\text { NTU }\end{array}$ \\
\hline $\begin{array}{l}\text { Electrical } \\
\text { conductivity }\end{array}$ & $0.165 \approx$ & $0.174 \mho$ & $0.183 \approx$ & $0.183 \approx$ & $0.183 \widetilde{J}$ \\
\hline $\begin{array}{l}\text { Dissolved } \\
\text { oxygen }\end{array}$ & $0.5 \mathrm{ppm}$ & $0.9 \mathrm{ppm}$ & $1.5 \mathrm{ppm}$ & $2.7 \mathrm{ppm}$ & $\begin{array}{l}3.9 \\
\text { ppm }\end{array}$ \\
\hline pH & 6.94 & 6.88 & 7.05 & 6.99 & 7.12 \\
\hline BOD & 195 ppm & $180 \mathrm{ppm}$ & $\begin{array}{l}174 \\
\text { ppm }\end{array}$ & $\begin{array}{l}163 \\
\text { ppm }\end{array}$ & $\begin{array}{l}155 \\
\text { ppm }\end{array}$ \\
\hline COD & $80 \mathrm{ppm}$ & $68 \mathrm{ppm}$ & $63 \mathrm{ppm}$ & 57 ppm & 48 ppm \\
\hline Chloride & $549 \mathrm{mg} / \mathrm{l}$ & $523 \mathrm{mg} / \mathrm{l}$ & $\begin{array}{l}485 \\
\mathrm{mg} / 1\end{array}$ & $\begin{array}{l}454 \\
\mathrm{mg} / 1\end{array}$ & $\begin{array}{l}386 \\
\mathrm{mg} / 1\end{array}$ \\
\hline Acidity & 0 & 0 & 0 & 0 & 0 \\
\hline Alkalinity & $12.5 \mathrm{mg} / \mathrm{l}$ & $36 \mathrm{mg} / 1$ & $\begin{array}{l}38.5 \\
\mathrm{mg} / \mathrm{l}\end{array}$ & $\begin{array}{l}37.2 \\
\mathrm{mg} / \mathrm{l}\end{array}$ & $\begin{array}{l}33.4 \\
\mathrm{mg} / \mathrm{l}\end{array}$ \\
\hline Total solids & $\begin{array}{l}2000 \\
\mathrm{mg} / 1\end{array}$ & $\begin{array}{l}1970 \\
\mathrm{mg} / \mathrm{l}\end{array}$ & $\begin{array}{l}1920 \\
\mathrm{mg} / \mathrm{l}\end{array}$ & $\begin{array}{l}1900 \\
\mathrm{mg} / \mathrm{l}\end{array}$ & $\begin{array}{l}1870 \\
\mathrm{mg} / \mathrm{l}\end{array}$ \\
\hline
\end{tabular}

Fig.8. Growth of the plant during the period in the wetland system

The Typha latifolia plant has grown considerably in the CW setup planted under sewage water. The height of the plant has grown from $45 \mathrm{~cm}$ in the time of planting it in the $\mathrm{CW}$ to $122 \mathrm{~cm}$ at the end of 4 weeks under the controlled environment.

The color of the water sample was yellowish colour in the initial weeks of treatment, but due to the formation of algae in the water sample, the colour of sewage water has changed to pale green. During the initial week of construction of the wetland, there was a stinky odor from the sewage water. As the weeks passed by the stinky smell has been reduced and there was no smell at the final 3 weeks, this indicates that the plant has started treating the sewage water. The temperature of the sample water remained the same at $27^{\circ} \mathrm{C}$ throughout the whole period of 4 weeks.

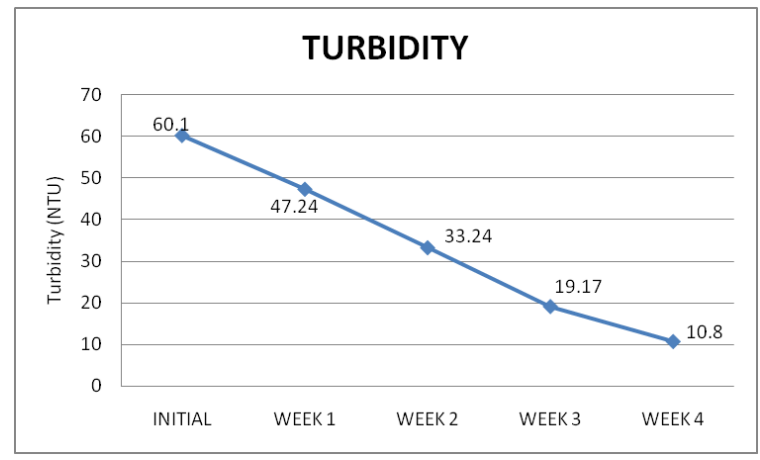

Fig.9. Variation of turbidity in the sample

The turbidity value of the sewage water was as high as 60.1 NTU before the water was used in the CW setup. The CW setup with Typha latifolia has considerably reduced the turbidity of the sewage water as the weeks pass by. At the end of the $4^{\text {th }}$ week, the turbidity value has considerably reduced to $10.8 \mathrm{NTU}$ which is about $82.02 \%$ lesser than the initial value. 


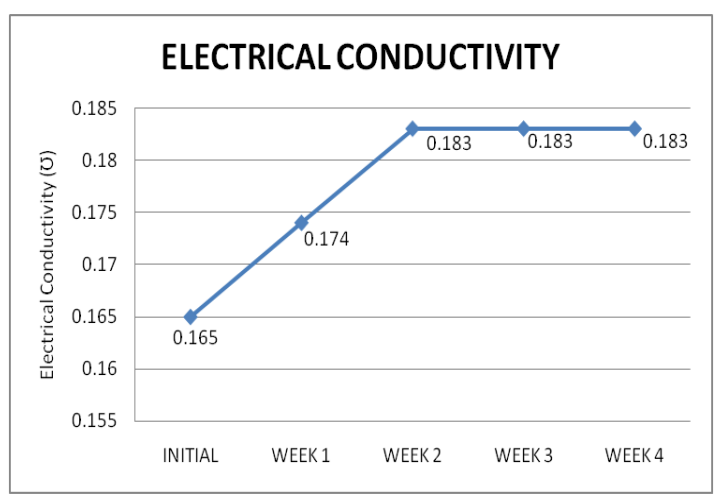

Fig.10. Variation of electrical conductivity in the sample

In the beginning, the electrical conductivity value was $0.165 \approx$ which kept on increasing to a value of $0.183 \approx$ during week 2 . Then after week 2 the electrical conductivity value remained the same until week 4.

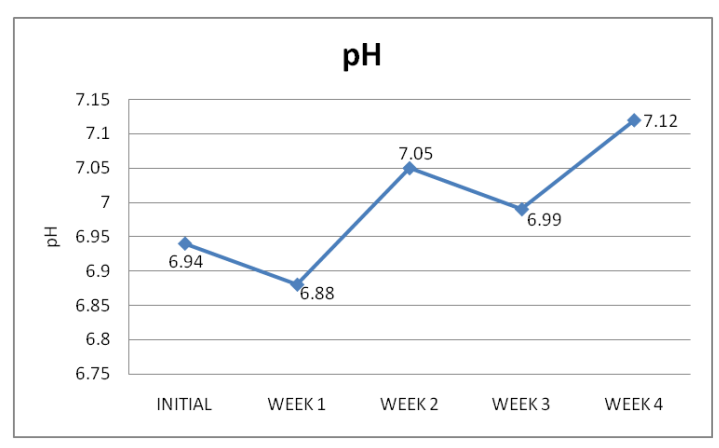

Fig. 11. Variation of $\mathrm{pH}$ in the sample

The $\mathrm{pH}$ value of sewage has been increasing and decreasing every week without any perfect pattern. While comparing the $\mathrm{pH}$ value of the initial and the final week there is an increase in the $\mathrm{pH}$ value from 6.94 to 7.12 .

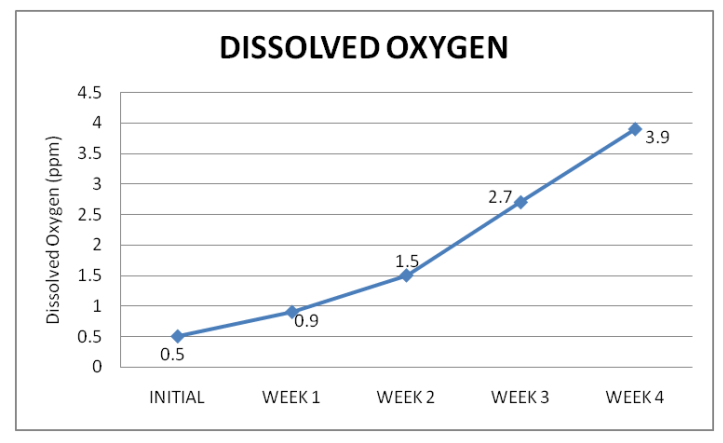

Fig.12. Variation of dissolved oxygen in the sample

In the CW system, the dissolved oxygen value has been considerably increasing throughout the period of 4 weeks. The DO value being $0.5 \mathrm{ppm}$ at the initial has increased at a higher rate to a value of $3.9 \mathrm{ppm}$ in the final week.

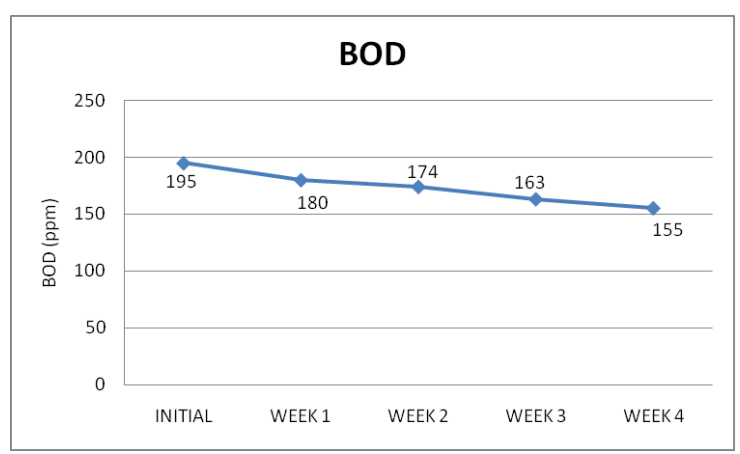

Fig.13. Variation of BOD content in the sample

$\mathrm{BOD}$ is one of the major parameters that has been reduced in the CW system. It has been reduced from $195 \mathrm{ppm}$ during the time when the plant is planted in the sewage at a rate of $20.51 \%$ to a value of $155 \mathrm{ppm}$ by the final week. This reduction in the BOD value indicates that Typha latifolia is effective in the treatment of sewage since BOD is one of the major parameters to be minimized in the treatment process of water.

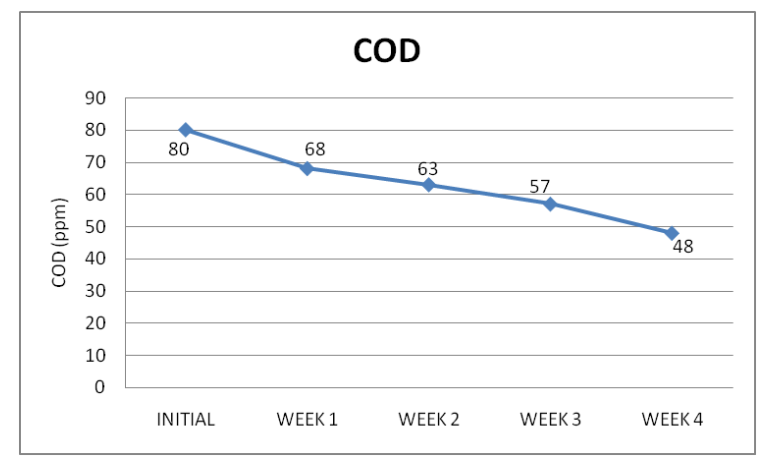

Fig.14. Variation of COD content in the sample

Along with the BOD reduction, the $\mathrm{CW}$ system has also reduced the COD content in the sewage water at a rate of $40 \%$ from $80 \mathrm{ppm}$ at the initial week to value to $48 \mathrm{ppm}$ during the week 4.

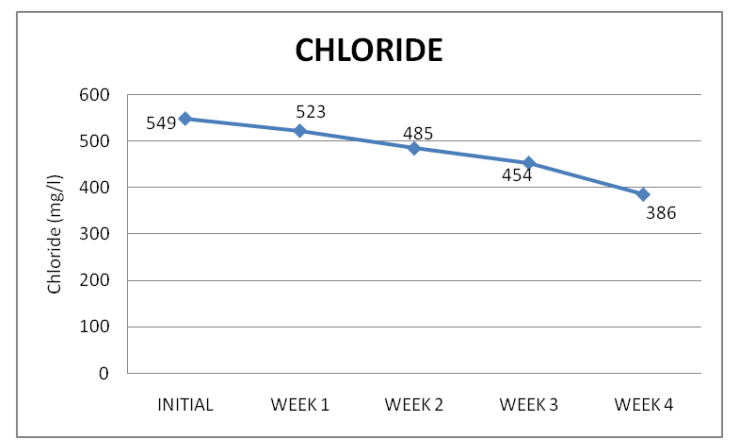

Fig. 15. Variation of chloride content in the sample

Chloride content is the most important parameter that is to be reduced in a water treatment process to make it safe. The chloride content indicates the saline nature of the water. The wetland has reduced the chloride content which is a good sign that the plant species Typha latifolia has effectively done the process of treatment of sewage water. It has reduced the chloride content from a high value of $549 \mathrm{mg} / \mathrm{l}$ to a value of $386 \mathrm{mg} / \mathrm{l}$ by the end of the investigation of the $\mathrm{CW}$ 
system. The chloride content has been reduced at a rate of $29.69 \%$ by the plant. Even though the chloride content is not within the safe limit of $250 \mathrm{mg} / \mathrm{l}$ by the end of week 4 ; it can be made safe if the time period of observance is increased as there is a considerable reduction in the chloride content in every week.

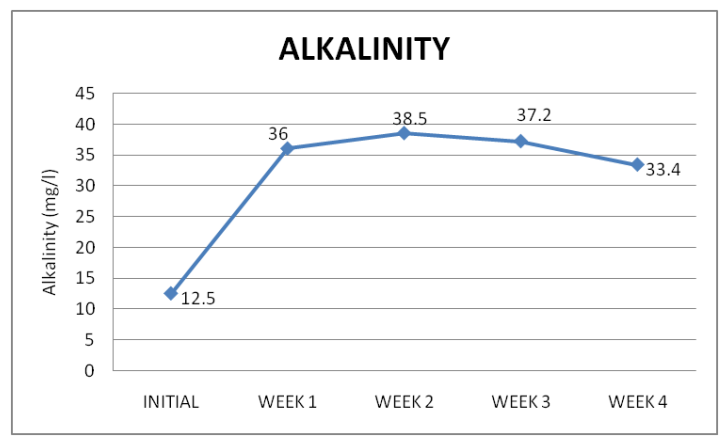

Fig. 16. Variation of alkalinity of the sample

There is no sign for the presence of any acidity content in the sample at any time period. The alkalinity of the sample has been the increasing side for the first two weeks from 12.5 $\mathrm{mg} / \mathrm{l}$ to $38.5 \mathrm{mg} / \mathrm{l}$ and it has considerably reduced during the last two weeks to a value of $33.4 \mathrm{mg} / \mathrm{l}$.

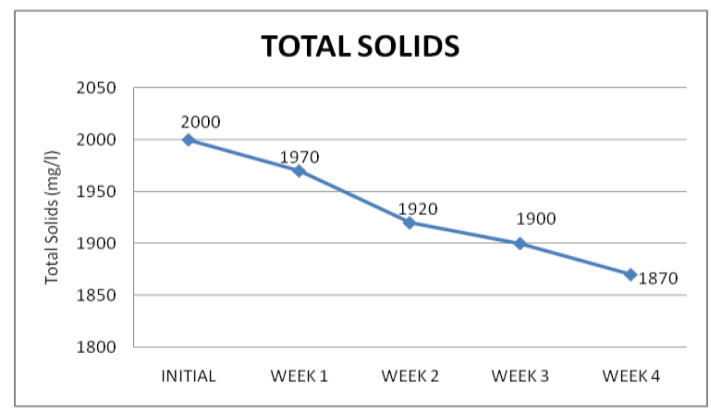

Fig.17. Variation of total solids present in the sample

The total solids content plays a vital role in determining the quality of the water. There is a gradual reduction in the amount of total solids present in the sewage. The CW system has reduced the amount of total solids $2000 \mathrm{mg} / \mathrm{l}$ to a value of $1870 \mathrm{mg} / \mathrm{l}$ at a rate of $6.5 \%$ during the treatment period of 4 weeks.

\section{CONCLUSION}

The plant species Typha latifolia has been grown in the constructed wetland system for a period of 4 weeks and the characteristics of the sewage water have been investigated every week. From the test performed on the sewage, it is found that as the time period increases the efficiency of the plant in treating the sewage also increases. Within the time period of 4 weeks, the plant has grown the height of $77 \mathrm{~cm}$ from its initial stage. The plant was highly effective in removing the chloride content, BOD and the COD present in the sewage. About $29.69 \%$ of chloride content, $20.51 \%$ of BOD and $40 \%$ of COD were reduced by Typha latifolia within a period of 4 weeks in the constructed wetland. The $\mathrm{CW}$ system can be an effective solution for the treatment of wastewater without releasing any effluent from the process of treatment. This method of treatment acts as an eco-friendly method of water treatment as it involves the growth of a plant, which on the other hand is a good sign for reducing the carbon dioxide content in the air.

\section{REFERENCES}

1. A.D. Karathanasis, C.L. Potter, M.S. Coyne. Vegetation effects on fecal bacteria, BOD, and suspended solid removal in constructed wetlands treating domestic wastewater, 2003.

2. Ahmed S., Performance evaluation study of root zone treatment plant at mother dairy, 2002.

3. Akaratos C.S., Tsihrintzis, V.A., Effect of temperature, HRT, vegetation and porous media on removal efficiency of pilot-scale horizonta subsurface flow constructed wetlands. Ecol. Eng. 29, 173-191, 2007.

4. Benyamine M, Bäckstrom N, Sanden P, Multi-objective environmenta management in constructed wetlands. Environ. Monitor. Assess. 2004, 90, 171-185.

5. Deblina Ghoshin, Effect of hydraulic retention time on the treatment of secondary effluent in a subsurface flow constructed wetland, Elsevier Journals, 2015.

6. Ghosh D, Gopal B, Effect of wetland plant species on the tertiary treatment of wastewater from a milk processing plant, 2007.

7. Guide des procédés épuratoires intensifs proposés aux petites collectivités, Nanterre, Agence de 1'Eau Seine Normandie, 1999.

8. Guidelines on the Safe Use of Wastewater, Excreta and Greywater. Volume 4: Excreta and Greywater Use in Agriculture, WHO/UNEP http://www.who.int/water_sanitation_health/wastewater/gsuweg4/en/in dex.html, WHO 2006.

9. Haiming $\mathrm{Wu}$, Jian Zhang, et al., A review on the sustainability of constructed wetlands for wastewater treatment: Design and operation, Elsevier Journals, 2015

10. Jan Vymazal, Constructed Wetlands for Wastewater Treatment, 27 August 2010

11. Jayakumar K.V., Dandigi M.N., A cost-effective environmentally friendly treatment of Municipal wastewater using constructed wetlands for developing countries, 2002.

12. Kapellakis I.E, Tsagarakis K.P, Angelakis, A.N. Performance of Free Water Surface Constructed Wetlands for Olive Mill Wastewater Treatment. In Proceedings of the 9th International Conference on Wetland Systems for Water Pollution Control; ASTEE: Lyon, France, 2004, pp. 113-120.

13. Keith R. Hench, Gary K. Bissonnette, et.al., Fate of physical, chemical and microbial contaminants in domestic wastewater following treatment by small construction wetlands, Water Research 37,2003.

14. Knight R.L, Payne V.W.E, Jr, Borer R.E, Clarke R.A, Constructed wetlands for livestock wastewater management. Ecol. Eng. 2000, 15, 41-55.

15. Knight R.L, Clarke R.A, Jr Bastian, R.K. Surface flow (sf) treatmen wetlands as a habitat for wildlife and humans. Wat. Sci. Tech. 2000, 44, 27-38.

16. Langergraber G, Giraldi D, Mena J, Meyer D, Peña M, Toscano A, Brovelli A, Korkusuz E.A, Recent developments in numerical modelling of subsurface flow constructed wetlands, Sci. Tot. Environment, 2009 , 407, 3931-3943

17. Lie-yu Zhang, Lan Zhang, et.al., Effect of limited artificial aeration on constructed wetland treatment of domestic wastewater, Elsevier Journals, November 2009.

18. O’Sullivan A.D, Moran B.M, Otte M.L., Accumulation and fate of contaminants $(\mathrm{Zn}, \mathrm{Pb}, \mathrm{Fe}$ and $\mathrm{S})$ in substrates of wetlands constructed for treating mine wastewater. Water Air Soil Pollut. 2004, 157, 345-364.

19. Pontier H, Williams J.B, May E, Progressive changes in water and sediment quality in a wetland system for control of highway runoff, Sci. Tot. Environ. 2004, 319, 215-224.

20. Principles for the Dimensioning, Construction and Operation of Planted Soilfiters for Urban Wastewater. German Association for Water Wastewater and Waste, DWA A 262, 2006.

21. R.M. Gersberg, B.V. Elkins, S.R. Lyon, C.R. Goldman. Role of Aquatic Plants in wastewater by Artifical Wetlands, Augest 1985.

22. Reed S.C., Crites R.W., Middlebrooks E.J., Natural Systems for Waste Management and Treatment, 2nd ed. McGraw Hill Professional, NY, 1995

23. T.Y. Chen, C.M. Kao, et. al. Application of a constructed wetland for industrial wastewater treatment: A pilot-scale study, Chemosphere, November 2005.

24. Tanner C.C.; Nguyen, M.L.; Sukias, J.P.S. Nutrient removal by a constructed wetland treating subsurface drainage from a grazed dairy pasture. Agric. Ecosyst. Environ. 2005, 105, 145-162. 
25. Tanveer Saeedin, Study of constructed wetlands with sugarcane bagasse for the treatment of textile wastewater, Elsevier Journals, 2012.

26. Thorén A.K, Legrand C, Hermann J, Transport and transformation of de-icing urea from airport runways in a constructed wetland system, Wat. Sci. Tech. 2003, 48, 283-290.

27. Tilley D.R, Badrinarayanan H, Rosati R, Son J, Constructed wetlands as recirculation filters in large-scale shrimp aquaculture. Aquacultural Eng. 2002, 26, 81-109.

28. Tonderski K.S, Grönlund E, Billgren C, Management of Sugar Effluent in the Lake Victoria Region. In Proceedings of the Workshop Wastewater treatment in Wetlands. Theoretical and Practical Aspects, Toczyłowska I, Guzowska G, Eds.; Gdańsk University of Technology Printing Office: Gdansk, Poland, 2005, pp. 177-184.

29. U. Stottmeister et al., Effects of plants and microorganisms in constructed wetlands for wastewater treatment, Elsevier Journals, 2003.

30. Variga Sawaittayothin, Nitrogen mass balance and microbial analysis of constructed wetlands treating municipal landfill leachate, Elsevier journals, 2010.

31. Vymazal J, Horizontal sub-surface flow and hybrid constructed wetlands for wastewater treatment. Ecol. Eng. 2005, 25, 478-490.

32. Vymazal J, Kropfelova L, is Concentration of Dissolved Oxygen a Good Indicator of Processes in Filtration Beds of Horizontal-flow Constructed Wetlands? In Wastewater Treatment, Plant Dynamics and Management; Vymazal J, Ed.; Springer: Dordrecht, The Netherlands, 2008, pp. 311-317.

33. Vymazal J, Removal of nutrients in various types of constructed wetlands. Sci. Tot. Environment, 2007, 380, 48-65.

34. Vymazal J, Types of Constructed Wetlands for Wastewater Treatment: Their Potential for Nutrient Removal. In Transformations of Nutrients in Natural and Constructed Wetlands, Vymazal J,Ed.; Backhuys Publishers: Leiden, The Netherlands, 2001, pp. 1-93.

\section{AUTHORS PROFILE}

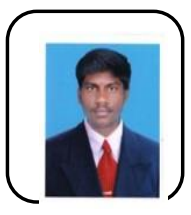

B. Kamal completed his Bachelor's degree in Civil Engineering at Sona College of Technology, Salem in the year 2013 and got his Master's degree in Environmental Engineering from Government College of Technology, Coimbatore in the year 2015. He is a Member of Indian Society of Technical Education. He has published 2 papers in International Journals and 4 papers National Journals. At present she is working as Assistant Professor at Sri Ramakrishna Engineering College, Coimbatore.

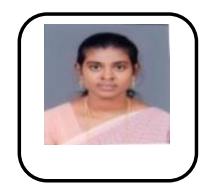

Anitha Selvasofia S.D. completed her U.G Degree in Civil Engineering in the year 2004 in Karunya Institute of Technology, Coimbatore. She completed her M.E Geo-Informatics in the year 2007 at College of Engineering, Guindy. She obtained her Ph.D. Degree on 'Identification of accident prone zone and minimizing the traffic congestion flow using GIS' in 2019 under Anna University, Chennai. She has published 11 papers in International Journals and 2 papers in International Conference and 3 papers in National conferences. She has organized 2 National Conferences. At present she is working as Assistant Professor (Sr.Gr) at Sri Ramakrishna Engineering College, Coimbatore.

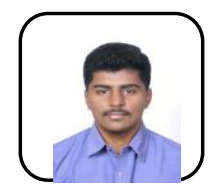

Santhosh P Y, Pursuing B.E Civil Engineering at Sri

Ramakrishna College Engineering, Coimbatore. 